\title{
MEMBANGUN SEMANGAT KERJA DENGAN LOYALITAS DAN KEPERCAYAAN DIRI PADA PEGAWAI
}

\author{
Yakup', \\ Fakultas Ekonomi Universitas Gorontalo \\ Anggita Permata Yakup, \\ Fakultas Ekonomi Universitas Gorontalo
}

\begin{abstract}
ABSTRAK
Penelitian ini bertujuan untuk menganalisis semangat kerja dengan meningkatkan Loyalitas dan Kepercayaan Diri Pegawai Bandara Jalaludin Gorontalo. Data penelitian diperoleh melalui penyebaran kuesioner yang bersumber dari angket yang diisi oleh responden. Populasi dan sampel penelitian adalah pegawai dengan jumlah sampel sebanyak 87 orang. Metode analisis penelitian menggunakan regresi linear berganda. Data diolah menggunakan aplikasi Statistical Product and Service Solutions (SPSS). Analisis data diawali dengan pengujian kualitas data melalui uji validitas dan reliabilitas data penelitian. Pengujian hipotesis dilakukan secara parsial dan uji simultan. Hasil analisis penelitian ditemukan bahwa semangat kerja pegawai dapat dibangaun atau ditingkatkan dengan penguatan loyalitas kerja dan kepemilikan kepercayaan diri pada pegawai. Jika pegawai memiliki loyalitas kerja yang tinggi dan didukung dengan kepemilikan kepercayaan diri yang tinggi, maka semangat kerja pegawai akan mengalami peningkatan.
\end{abstract}

Kata Kunci: Semangat Kerja; Loyalitas Kerja; Kepercayaan Diri

\begin{abstract}
This study aims to analyze work morale by increasing the loyalty and self-confidence of the employees of Jalaludin Airport, Gorontalo. The research data was obtained through distributing questionnaires that originated from questionnaires filled out by respondents. The population and research sample are employees with a total sample of 87 people. Method used for research analysis was multiple linear regression. The data was processed using Statistical Product and Service Solutions (SPSS) applications. The data analysis begins with testing the quality of the data through the validity and reliability of the research data. Hypothesis testing is done partially and simultaneously. The results of the research analysis found that employees' morale can be built or improved by strengthening work loyalty and self-confidence in employees. If employees have high work loyalty and are supported by high self-confidence, then employees' morale will increase.
\end{abstract}

Keywords: Spirit at work; Job Loyalty; Confidence

\footnotetext{
${ }^{1}$ Program Studi Magister Manajemen. yakup.ug@gmail.com
} 


\section{9 | Bina Ekonomi}

\section{PENDAHULUAN}

Perkembangan organisasi saat ini dituntut dengan kesiapan sumber daya manusia yang memiliki berbagai kemampuan dalam melaksanakan berbagai tugas-tugas sesuai posisi dan kewenangan yang diberikan kepadanya. Semangat kerja seseorang sangat mempengaruhi kualitas hasil pekerjaan yang dilaksanakannya. Semangat kerja yang tinggi diperlihatkan melalui kesedian bekerja keras, tekun dan bergairah yang secara terus menerus terarah pada pencapaian tujuan organisasi. Menurut Nitisemito (Zahara, 2014), semangat kerja adalah melakukan pekerjaan secara lebih giat sehingga dengan demikian pekerjaan dapat diharapkan lebih cepat dan lebih baik. Dengan semangat kerja yang tinggi, berarti seseorang mau melaksanakan tugas dengan sungguh-sungguh, sehingga pekerjaan dapat diselesaikan dengan cepat sesuai waktu yang ditetapkan.

Semangat kerja yang dimiliki seseorang akan lebih meningkat bila sumber-sumbernya berasal dari dalam dirinya sendiri, dan bukan semata-mata karena ada imbalan yang akan diterimanya. Semangat kerja yang bersumber dari dalam diri yaitu adanya loyalitas atau kesetiaan terhadap pekerjaan dan organisasinya yang akan memberikan kesejahteraan dan keamanan dalam pekerjaannya. Vionita, dkk. (2017) dalam penelitiannya menunjukkan bahwa semangat kerja sangat ditentukan oleh loyalitas yang dimiliki seseorang. Individu yang tidak loyal pada organisasinya memiliki kecenderungan semangat kerja yang rendah. Fenomena penurunan semangat kerja pegawai ditandai dengan rendahnya keterlibatan dalam pekerjaan, kurangnya gairah dalam pekerjaan, dan kurangnya kedisiplinan pegawai dalam mematuhi aturan dalam organisasi. Penurunan ini merupakan implikasi dari loyalitas kerja yang rendah dan kurangnya kepercayaan diri pada pegawai.

Menurut Rasimin (1988), loyalitas mencerminkan kesetiaan, pengabdian dan kepercayaan yang yang dimiliki seseorang kepada organisasinya, di mana di dalamnya terdapat rasa cinta dan tanggung jawab untuk berusaha memberikan pelayanan dan perilaku terbaiknya. Loyalitas kerja para pegawai terhadap organisasi akan dapat menimbulkan rasa tanggung jawab serta menciptakan gairah dan semangat kerja. Pada penelitian yang dilakukan oleh Vionita, dkk. (2017) dan Sujiyanto (2017), menunjukkan bahwa loyalitas kerja karyawan memberikan kontribusi positif terhadap semangat kerja yang berdampak pula pada peningkatan kinerja. Tingginya kinerja pegawai merupakan hasil dari semangat kerja pegawai dalam melaksnakan tugasnya.

Faktor lain yang secara teoritis maupun empiris memberikan dorongan semangat yang bersumber dari dalam diri adalah adanya rasa pecaya diri yang dimiliki seseorang dalam menjalankan tugasnya. Percaya diri adalah keyakinan pada kemampuan dan penilaian diri sendiri dalam melakukan tugas dan memilih pendekatan yang efektif. Kepercayaan diri mencerminkan kemampuannya menghadapi lingkungan yang semakin menantang dan kepercayaan atas keputusan atau pendapatnya. Inge (Masturina, 2018) menyatakan bahwa kepercayaan diri adalah keyakinan seseorang pada kemampuan yang dimiliki dengan menunjukan perilaku terbaiknya dalam mencapai target yang telah ditetapkan. Kepercayaan diri merupakan kontrol internal, perasaan akan adanya sumber kekuatan dalam diri, sadar akan kemampuan dan bertanggung jawab terhadap keputusan-keputusan yang telah ditetapkannya.

Hakim (2002) menyatakan bahwa orang yang percaya diri mampu menjalankan tugastugas dengan baik dan bertanggung jawab serta mempunyai rencana terhadap masa depannya, kreatif, toleransi, dalam pekerjaannya dan biasanya orang tersebut mempunyai keyakinan pada 
diri sendiri. Seorang pegawai membutuhkan kepercayaan diri untuk berhasil dalam hidupnya, rasa percaya diri berperan dalam memberikan semangat serta memotivasi individu untuk bereaksi secara tepat terhadap tantangan dan kesempatan yang datang padanya maupun untuk merasakan berbagai kebahagiaan dalam hidupnya. Kepercayaan diri yang ada pada diri pegawai akan memberikan manfaat yang sangat berharga bagi pegawai itu sendiri, yaitu pada saat pegawai diberikan setiap tugas maka dia akan tampil dengan penuh rasa percaya diri yang pada akhirnya akan menimbulkan semangat kerja yang tinggi. Penelitian Yusuf dan Hamzah (2016), dan Juniari, dkk. (2015) menyimpulkan bahwa kepercayaan diri menimbulkan minat yang besar dan efikasi diri yang kuat sebagai kekuatan sebagai wujud dari semangat kerja yang dimiliki seseorang.

Pegawai Bandar Udara sebagai pengelola transportasi udara memiliki tugas dan tanggungjawab terselenggaranya transportasi udara yang aman, nyaman dan terjaminnya keselamatan bagi operator dan pengguna jasa transportasi. Tugas dan tanggung jawab ini membutuhkan pegawai yang memiliki semangat kerja yang tinggi.

Berdasarkan latar belakang diatas, maka tujuan penelitian ini adalah; (1) menganalisis pengaruh loyalitas terhadap semangat kerja pegawai, (2) menganalisis pengaruh kepercayaan diri terhadap semangat kerja pegawai.

\section{TINJAUAN PUSTAKA}

\subsection{Semangat Kerja}

Menurut Davis dalam Alwi, dkk. (2016), semangat kerja merupakan sikap individu dan kelompok terhadap aktivitas organisasi dan hubungannya dengan orang lain yang dilakukan secara maksimal dalam mencapai kepentingan bersama. Pegawai yang memiliki semangat dan gairah kerja yang tinggi, akan berusaha untuk dapat menyelesaikan pekerjaan lebih cepat dari target yang ditetapkan. Pendapat yang sama juga dikemukakan oleh Hasanah yang dikutip oleh Subari (2019) yang mengemukakan bahwa semangat kerja adalah kemauan dan kesenangan yang mendalam terhadap pekerjaan yang dilakukan. Jadi, semangat kerja dapat dimaknai sebagai perasaan senang yang bersumber dari dalam diri seseorang pada saat melakukan pekerjaan.

Sejalan dengan pendapat diatas, Nitisemito dalam Kuncoro (2017) mengemukakan bahwa semangat kerja adalah melakukan pekerjaan secara lebih giat sehingga pekerjaan diharapkan lebih cepat dan hasilnya lebih baik. Berdasarkan pendapat para ahli tersebut, maka dapat diketahui bahwa semangat kerja yang dimiliki oleh pegawai diperlihatkan melalui kesediaan bekerja keras, ketekunan yang dilakukan secara terus menerus dan terarah pada pencapaian tujuan organisasi. Davis dalam Alwi, dkk. (2016) menyatakan bahwa indikator untuk mengukur semangat kerja pegawai bisa dilihat dari (1) kegairahan kerja, yaitu antusias dan kreatif dalam bekerja; (2) adanya kepuasan kerja dengan perasaan senang terhadap pekerjaan, tiada keluhan dalam bekerja dan dapat menyelesaikan pekerjaan sesuai dengan sasaran; (3) adanya kerja sama pegawai yaitu terciptanya hubungan kerja yang harmonis baik terhadap atasan maupun terhadap rekan kerja.

\subsection{Loyalitas Kerja}

Menurut Hasibuan dalam Saputra, dkk. (2016), loyalitas kerja adalah berbagai bentuk peran serta anggota dalam menggunakan tenaga dan pikiran serta waktunya dalam mewujudkan 


\section{1 | Bina Ekonomi}

tujuan organisasi. Hal serupa dikemukakan Onsardi (2018) di mana menurutnya loyalitas adalah kesetiaan dan kepatuhan seorang atau sekelompok karyawan terhadap organisasi di mana ia melaksanakan pekerjaan sehari-hari. Dalam praktiknya, loyalitas kerja akan tercermin pada sikap di mana pegawai mencurahkan kemampuan dan keahlian yang dimilikinya dalam melaksanakan tugas dan tanggung jawabnya, menjaga hubungan baik dengan atasan, bekerja sama dengan rekan kerja, serta menjaga nama baik organisasi.

Pendapat yang sama juga dikemukakan oleh Agustini dalam Pradana dan Nugraheni (2015) yang menyatakan loyalitas kerja merupakan tekad dan kesanggupan untuk mentaati, melaksanakan dan mengamalkan sesuatu yang ditaati dengan penuh kesadaran dan tanggung jawab. Sedangkan menurut Rasimin dalam Syaputra, dkk. (2017) loyalitas kerja diartikan sebagai kesetiaan, pengabdian dan kepercayaan yang diberikan atau ditujukan kepada seorang pegawai, yang di dalamnya terdapat rasa cinta dan tanggung jawab untuk berusaha memberikan pelayanan dengan perilaku terbaik. Dalam pandangan ini, terlihat bahwa loyalitas kerja pada pegawai merupakan hal yang sangat penting untuk dimiliki, karena dengan loyalitas kerja yang tinggi pegawai akan dapat menampilkan kinerja terbaiknya untuk kemajuan organisasi. Pengukuran loyalitas kerja menurut Siswanto dalam Saputra, dkk. (2016): (1) taat pada peraturan, (2) tanggung jawab pekerjaan, (3) rasa memiliki, (4) hubungan antar pribadi, dan (5) kesukaan terhadap pekerjaan.

\subsection{Kepercayaan Diri}

Kepercayaan diri merupakan salah satu syarat utama bagi seorang pegawai dalam melaksanakan tugas dan tanggung jawabnya. Kepercayaan diri atau self confidence menurut Lauser dalam Syam dan Amri (2017) merupakan sikap atau keyakinan atas kemampuan diri sendiri, sehingga dalam melaksanaan pekerjaan tidak akan ragu-ragu, merasa bebas untuk melakukan hal-hal sesuai dengan tugas dan tanggung jawabnya, sopan dalam berinteraksi, memiliki dorongan untuk berprestasi, serta mengenal kelebihan dan kekurangan pada dirinya. Pendapat serupa dikemukakan Ghufron dalam Afifah, dkk. (2019) yakni kepercayaan diri merupakan sikap mental seseorang dalam menilai diri maupun objek sekitarnya sehingga orang tersebut mempunyai keyakinan akan kemampuan dirinya untuk dapat melakukan sesuatu sesuai dengan kemampuannya. Orang yang tidak memiliki kepercayaan diri cenderung memiliki perasaan takut di hadapan orang banyak, pasrah pada kegagalan, kurang mencintai pekerjaan, serta cenderung berusaha menghindari tugas dan tanggung jawab.

Menurut Hakim dalam Nurani, dkk. (2018) kepercayaan diri adalah keyakinan seseorang terhadap segala aspek kelebihan yang dimiliki dan membuat kemampuan untuk mencapai berbagai tujuan hidup. Rasa percaya diri seseorang diperlihatkan melalui keberaniannya dalam menghadapi tantangan karena memberi suatu kesadaran bahwa belajar dari pengalaman jauh lebih penting dari pada keberhasilan atau kegagalan. Kepercayaan diri penting dimiliki dalam melaksanakan tugas dan berhadapan dengan masyarakat, karena rasa percaya diri dapat meningkatkan efektivitas kerja. Menurut Fatimah dalam Nurani, dkk. (2018) ciri individu yang mempunyai rasa percaya diri terdiri dari (1) percaya pada kemampuannya sendiri, (2) berani menjadi diri sendiri, (3) memiliki pengendalian diri, (4) memiliki cara pandang positif, dan (5) memiliki harapan realistik. 


\section{METODE DAN DATA}

Desain penelitian bersifat deskriptif kualitatif menganalisis semangat kerja pegawai dengan memasukan variabel loyalitas kerja dan kepercayaan diri. Data penelitian diperoleh melalui penyebaran kuesioner kepada responden yaitu pegawai Bandar Udara Jalaludin Gorontalo dengan responden sebanyak 87 orang. Analisis data dilakukan secara statistik dengan metode analisis yang digunakan yakni regresi linear berganda dengan persamaan:

$$
Y=b_{0}+b_{1} X_{1}+b_{2} X_{2}
$$

Pengolahan data dipergunakan aplikasi Statistik program SPSS.

\section{PEMBAHASAN}

a. Karakteristik Responden

Tabel 1. Jenis Kelamin

\begin{tabular}{ccc}
\hline \multicolumn{1}{c}{ Keterangan } & Jumlah Responden & Persentase \\
\hline Perempuan & 36 & 41,4 \\
Laki - Laki & 51 & 58,6 \\
\multicolumn{1}{c}{ Total } & 87 & 100 \\
\hline
\end{tabular}

Sumber : Hasil pengolahan Data

Pada tabel diatas, responden terbanyak adalah pegawai dengan jenis kelamin lakilaki sebesar $58,6 \%$ dan sisanya berjenis kelamin perempuan sebesar $41,4 \%$.

Tabel 2. Pendidikan Terakhir

\begin{tabular}{lcc}
\hline \multicolumn{1}{c}{ Pendidikan } & Jumlah Responden & Persentase \\
\hline SMK & 17 & 19,5 \\
Diploma & 29 & 33,3 \\
Sarjana & 41 & 47,1 \\
\multicolumn{1}{c}{ Total } & 87 & 100 \\
\hline
\end{tabular}

Sumber : Hasil pengolahan Data

Berdasarkan tabel diatas, bahwa pegawai yang menjadi responden sebagian besar pendidikan sarjana sebanyak $47,1 \%$. Dari data tersebut dapat diketahui rata-rata pegawai berpendidikan sarjana.

b. Uji Validitas

Tabel 3. Hasil Uji Validitas Semangat Kerja

\begin{tabular}{cccc}
\hline No. Butir & $\mathbf{R}_{\text {tabel }}$ & $\mathbf{R}_{\text {hitung }}$ & Keterangan \\
\hline 1 & 0,207 & 0,249 & Valid \\
2 & 0,207 & 0,336 & Valid \\
3 & 0,207 & 0,462 & Valid \\
4 & 0,207 & 0,431 & Valid \\
5 & 0,207 & 0,368 & Valid \\
6 & 0,207 & 0,518 & Valid \\
\hline
\end{tabular}

Sumber : Hasil pengolahan Data

Dari hasil diatas besarnya r-hitung lebih besar dari nilai r-tabel, dimana nilai $r$ - 


\section{3 | Bina Ekonomi}

tabel sebesar 0,207 pada tingkat signifikansi 5\%. Maka, keseluruhan butir-butir kuesioner variabel semangat kerja dinyatakan valid dan dapat dipergunakan sebagai alat ukur variabel penelitian.

Tabel 4. Hasil Uji Validitas Loyalitas Kerja

\begin{tabular}{cccc}
\hline No. Butir & $\mathbf{R}_{\text {tabel }}$ & $\mathbf{R}_{\text {hitung }}$ & Keterangan \\
\hline 1 & 0,207 & 0,306 & Valid \\
2 & 0,207 & 0,470 & Valid \\
3 & 0,207 & 0,303 & Valid \\
4 & 0,207 & 0,269 & Valid \\
5 & 0,207 & 0,323 & Valid \\
6 & 0,207 & 0,434 & Valid \\
\hline
\end{tabular}

Sumber : Hasil pengolahan Data

Dari hasil diatas besarnya r-hitung lebih besar dari nilai r-tabel, dimana nilai $r$ tabel sebesar 0,207 pada tingkat signifikansi 5\%. Maka keseluruhan butir-butir kuesioner variabel loyalitas kerja dinyatakan valid dan dapat dipergunakan sebagai alat ukur variabel penelitian.

Tabel 5. Hasil Uji Validitas Kepercayaan Diri

\begin{tabular}{cccc}
\hline No. Butir & $\mathbf{R}_{\text {tabel }}$ & $\mathbf{R}_{\text {hitung }}$ & Keterangan \\
\hline 1 & 0,207 & 0,456 & Valid \\
2 & 0,207 & 0,372 & Valid \\
3 & 0,207 & 0,365 & Valid \\
4 & 0,207 & 0,392 & Valid \\
5 & 0,207 & 0,472 & Valid \\
6 & 0,207 & 0,518 & Valid \\
\hline
\end{tabular}

Sumber : Hasil pengolahan Data

Dari hasil diatas besarnya r-hitung lebih besar dari nilai r-tabel, dimana nilai $r$ tabel sebesar 0,207 pada tingkat signifikansi 5\%. Maka keseluruhan butir - butir kuisioner variabel kepercayaan diri dinyatakan valid dan dapat dipergunakan sebagai alat ukur variabel penelitian.

c. Uji Reliabilitas

Reliabilitas adalah alat ukur suatu kuesioner yang merupakan indikator dari variabel penelitian. Suatu kuesioner dikatakan andal jika jawaban responden terhadap pernyataan konsisten atau stabil dari waktu ke waktu. Apabila nilai cronbach alpha dari hasil pengujian > 0,60 maka dapat dikatakan bahwa variabel itu adalah reliabel. Hasil analisis uji reliabilitas dapat dilihat pada tabel dibawah ini.

Tabel 6. Hasil Uji Reliabilitas Kuisioner

\begin{tabular}{lccc}
\hline \multicolumn{1}{c}{ Variabel } & Nilai Alpa & Hasil Uji & Keterangan \\
\hline Kepercayaan Diri & 0,60 & 0,614 & Reliabel \\
Loyalitas Kerja & 0,60 & 0,697 & Reliabel \\
Semangat Kerja & 0,60 & 0,664 & Reliabel \\
\hline
\end{tabular}

Sumber : Hasil pengolahan Data 
Hasil uji reliabilitas menunjukan ketiga variabel yang diteliti memiliki cronbach alpha lebih besar dari 0,60. Maka kuesioner untuk setiap variabel memiliki keandalan yang konsisten.

\section{d. Pengujian Hipotesis}

Berikut adalah hasil dari analisis dengan menggunakan SPSS, disajikan dalam tabel berikut.

Tabel 7. Hasil Regresi Linear Berganda

\begin{tabular}{|c|c|c|c|c|c|}
\hline \multirow[t]{2}{*}{ Variabel } & \multicolumn{2}{|c|}{$\begin{array}{c}\text { Unstandardized } \\
\text { Coefficients }\end{array}$} & \multirow{2}{*}{$\begin{array}{c}\text { Standardized } \\
\text { Coefficients } \\
\text { Beta }\end{array}$} & \multirow[t]{2}{*}{$\mathbf{t}$} & \multirow[t]{2}{*}{ Sig. } \\
\hline & B & Std. Error & & & \\
\hline (Constant) & 7,829 & 1,694 & & 4,623 & 0,000 \\
\hline Loyalitas Kerja & 291 & ,076 & 0,332 & 3,833 & 0,000 \\
\hline Kepercayaan diri & ,459 & ,073 & 0,546 & 6,308 & 0,000 \\
\hline$F_{\text {hitung : }}$ & 77,662 & & & & $0,000^{\mathrm{b}}$ \\
\hline $\mathrm{R}$ & $0,806^{a}$ & & & & \\
\hline $\mathrm{R}^{2}$ & 0,649 & & & & \\
\hline
\end{tabular}

Sumber : Hasil pengolahan Data

Pada tabel di atas di peroleh persamaan regresi:

$$
Y=7,829+0,833 X_{1}+0,546 X_{2}
$$

a) Nilai konstanta (a) $=7,829$. Nilai ini menunjukan semangat kerja pegawai, di mana tanpa adanya loyalitas kerja dan kepercayaan diri, maka akan konstan pada angka 7,829 .

b) Koefisien regresi loyalitas kerja $\left(b_{1}\right)=0,332 X_{1}$, memberikan makna bahwa setiap peningkatan nilai loyalitas kerja sebesar satu satuan akan diikuti dengan peningkatan semangat kerja pegawai sebesar 0,332 satuan.

c) Koefisien regresi kepercayaan diri $\left(b_{1}\right)=0,546 \mathrm{X}_{2}$, memberikan makna bahwa setiap peningkatan nilai kepercayaan diri sebesar satu satuan akan diikuti dengan peningkatan semangat kerja pegawai sebesar 0,546 satuan.

Koefisien determinasi $\left(\mathrm{R}^{2}\right)=0,649$, menunjukan bahwa loyalitas kerja dan kepercayaan diri memiliki kemampuan dalam menjelaskan variasi perubahan semangat kerja sebesar $64,9 \%$, sedangkan sisanya sebesar 35,1\% dipengaruhi oleh faktor lain di luar variabel penelitian ini.

1. Loyalitas Kerja pada Semangat Kerja

Pada tabel $7 \mathrm{di}$ atas memperlihatkan bahwa loyalitas kerja terhadap semangat kerja menunjukan hasil yang signifikan. Pegawai yang memiliki loyalitas kerja yang tinggi akan mencurahkan segala perhatian, tenaga dan pikirannya semata-mata untuk kemajuan organisasinya. Loyalitas kerja akan diperlihatkan pada setiap pelaksanaan pekerjaan yang sudah menjadi tanggung jawabnya untuk dikerjakan sesuai dengan petunjuk kerja, tanpa harus menunggu perintah dari atasannya. Pegawai yang loyal terhadap pekerjaanya diekspresikan sebagai wujud kesetiaanya yang akan menambah bobot semangat kerjanya dalam melaksanakan tugasnya. 


\section{5 | Bina Ekonomi}

Pengaruh positif dan signifikan loyalitas kerja terhadap pegawai dapat meningkat karena didukung oleh adanya pegawai yang mentaati peraturan, pegawai melaksanakan pekejaan sesuai tanggung jawabnya, pegawai merasa memiliki organisasi, dan adanya hubungan pribadi atau ikatan emosional pegawai pada organisasi, sehingga pegawai selalu berusaha dengan segala kemampuannya, dan juga menyukai pekerjaan yang ditugaskan kepadanya. Sehingga, dengan loyalitas kerja yang tinggi, maka semangat kerja pegawai juga mengalami peningkatan. Reichheld (Soegandhi, dkk, 2013) menjelaskan bahwa semakin tinggi loyalitas para karyawan di suatu organisasi, maka semakin mudah bagi organisasi itu untuk mencapai tujuan-tujuan organisasi yang telah ditetapkan sebelumnya oleh pemilik organisasi. Dengan kepemilikan loyalitas kerja dalam organisasi, ini berhubungan erat dengan dorongan yang kuat untuk tetap menjadi anggota organisasi, dan berusaha sekuat tenaga untuk kemajuan organisasi. Bila seseorang memiliki loyalitas dan kepercayaan terhadap suatu hal, maka orang tersebut bersedia berkorban dan setia terhadap hal yang dipercayainya tersebut. Jadi, loyalitas memiliki hubungan positif terhadap tingkat kepercayaan, di mana semakin tinggi tingkat kepercayaan pegawai terhadap organisasi, maka semakin tinggi pula tingkat loyalitas pegawai tersebut terhadap organisasinya. Hasil temuan penelitian ini sejalan dengan temuan penelitian yang dilakukan Vionita, dkk. (2017) dan Sujiyanto (2017) bahwa loyalitas kerja pengaruh terhadap semangat kerja. Hal ini berarti semakin tinggi loyalitas kerja akan berdampak pada semakin tingginya semangat kerja pegawai.

\section{Kepercayaan Diri pada Semangat Kerja}

Berdasarkan tabel 7 diatas menunjukan kepercayaan diri kerja terhadap semangat kerja menunjukan hasil yang signifikan. Pegawai yang memiliki kepercayaan diri yang tinggi akan memperlihatkan semangat kerja yang tinggi pula. Hal ini juga dapat diperlihatkan dalam penampilannya pada setiap pekerjaan atas kemampuannya terhadap orang lain bahwa dia memiliki kelebihan dibandingkan dengan orang lain. Peningkatan kepercayaan diri pegawai dicirikan dimana pegawai percaya pada kemampuannya sendiri, pegawai menjadi dirinya sendiri, pegawai memiliki pengendalian diri yang baik, pegawai memiliki cara pandang yang positif, serta memiliki harapan yang realistik. Dengan adanya kepercayaan diri yang dimiliki pegawai dalam melaksanakan tugas-tugas yang diberikan kepadanya menjadikan semangat kerja lebih meningkat.

Hasil temuan sejalan dengan pendapat Inge (Masturina, 2018) bahwa kepercayaan diri merupakan keyakinan seseorang akan kemampuan yang dimiliki untuk menampilkan perilaku tertentu atau untuk mencapai target tertentu. Kepercayaan diri merupakan pengendalian internal, perasaan akan adanya sumber kekuatan dalam diri, sadar akan kemampuannya dan bertanggung jawab terhadap keputusan yang ditetapkannya. Rasa percaya diri dan ketenangan merupakan hasil pengembangan sejumlah keahlian untuk menyelesaikan sebuah tugas dengan sukses. Kepercayaan diri menjadi kunci utama penentu keberhasilan seseorang. Individu yang memiliki kepercayaan diri yang tinggi akan mudah menyesuaikan diri dalam lingkungan manapun. Hasil temuan penelitian ini sejalan dengan temuan penelitian yang dilakukan Firdausi (2018) serta Yusuf dan Hamzah (2016), di mana kepercayaan diri memiliki pengaruh terhadap semangat kerja pegawai. Hal ini berarti 
semakin tinggi kepercayaan diri, maka semangat kerja pegawai akan semakin meningkat.

\section{SIMPULAN}

Berdasarkan hasil analisis, maka dapat ditarik kesimpulan bahwa loyalitas kerja berpengaruh positif dan signifikan terhadap semangat kerja pegawai. Artinya, jika pegawai memiliki memiliki loyalitas yang tinggi terhadap pekerjaan dan organisasi, maka pegawai memiliki semangat kerja yang tinggi pula. Kepercayaan diri memberikan sumbangan positif dan signifikan terhadap semangat kerja pegawai. Dengan kepercayaan diri yang dimiliki pegawai, maka akan menambah semangat kerja dalam melaksanakan pekerjaan yang ditugaskan kepadanya. Dengan demikian, jika pegawai memiliki loyalitas yang tinggi pada pekerjaan dan organisasinya serta didukung oleh kepercayaan diri yang tinggi, maka akan lebih menambah bobot semangat kerja pegawai dalam melaksankaan setiap tugas yang diberikan kepadanya. 


\section{7 | Bina Ekonomi}

\section{DAFTAR PUSTAKA}

Afifah, A., Hamidah, D., \& Burhani, I. (2019, Juni). Studi Komparasi Tingkat Kepercayaan Diri (Self Confidence) Siswa Antara Kelas Homogen Dengan Kelas Heterogen Di Sekolah Menengah Atas. Happiness, Vol. 3 No. 1.

Alwi, M., Sylvana, A., \& Risnashari. (2016, Juni). Pengaruh Semangat Kerja Pegawai Terhadap Keefektifan Organisasi Unit Program Belajar Jarak Jauh Universitas Terbuka Makassar. Jurnal analisis dan Pelayanan Publik, Vol. 2 No. 1.

Firdausi, A. (2018, April). Pengaruh Supervisi dan Kepercayaan Diri Terhadap Kepuasan Kerja Guru SMKN di Jakarta Timur. Jurnal Sap, Vol. 2 No. 3.

Hakim, T. (2002). Mengatasi Rasa Tidak Percaya Diri. Jakarta: Puspa Swara.

Juniari, N. K., Riana, I. G., \& Subudi, M. (2015). Pengaruh Motivasi Terhadap Kepuasan Kerja dan Kinerja Pegawai Negeri Sipil (PNS) Di Sekolah Tinggi Pariwisata Nusa Dua Bali. Jurnal Ekonomi dan Bisnis Universitas Udayana, Vol. 4 No. 11, 823-840.

Kuncoro, S. B. (2017). Pengaruh Kualitas Pelayanan dan Semangat Kerja Pegawai Terhadap Kepuasan Masyarakat di Kantor Kecamatan Bengalon Kabupaten Kutai Timur. e-Journal Pemerintahan Integratif, Vol. 5 No. 2.

Masturina, D. (2018). Pengaruh Kompetensi Diri Dan Kepercayaan Diri Terhadap Perencanaan Karir Mahasiswa Program Studi Peternakan Universitas Mulawarman. Jurnal Psikoborneo, Vol. 6 No. 2, 340-350.

Nurani, Sunarto, \& Wardani, D. K. (2018). Pengaruh Kepercayaan Diri dan Motivasi Belajar Peserta Didik Pada Mata Pelajaran Ekonomi di SMA Negeri 8 Surakarta. Jurnal Pendidikan Bisnis dan Ekonomi, Vol. 4 No. 2.

Onsardi. (2018, Juli-Desember). Loyalitas Karyawan Pada Universitas Swasta di Kota Bengkulu. Journal of Economic, Business, and Accounting (Costing), Vol. 2 No. 1.

Pradana, R., \& Nugraheni, R. (2015). Analisis Pengaruh Kepuasan Kerja, Loyalitas Kerja, Dan Lingkungan Kerja Non Fisik Terhadap Kinerja Karyawan (Studi Pada Bank Indonesia Kota Semarang). Diponegoro Journal of Management, Vol. 4 No. 4.

Rasimin, B. S. (1988). Individu dalam Industri dan Organisasi. Yogyakarta: Fakultas Ekonomi UGM.

Saputra, A. T., Bagia, I. W., \& Yulianthini, N. N. (2016). Pengaruh Kepuasan Kerja Dan Loyalitas Karyawan Terhadap Kinerja Karyawan. e-Journal Bisma Universitas Pendidikan Ganesha Jurusan Manajemen, Vol. 4.

Soegandhi, V. M., Sutanto, E. M., \& Setiawan, R. (2013). Pengaruh Kepuasan Kerja Dan Loyalitas Kerja Terhadap Organizational Citizenship Behavior Pada Karyawan Pt. Surya Timur Sakti Jatim. AGORA, Vol. 1 No. 1.

Subari. (2019, Agustus). Pengaruh Semangat Kerja Dan Kepuasan Kerja Terhadap Kualitas Pelayanan Aparatur Sipil Negara Pada Kantor Kecamatan Way Seputih Kabupaten Lampung Tengah. Jurnal Simplex, Vol. 2 No. 2.

Sujiyanto. (2017, Agustus). Pengaruh Integritas Dan Loyalitas Pegawai Terhadap Kebijakan Pimpinan Dan Dampaknya Terhadap Kinerja Di Lingkungan Dinas Komunikasi Dan 
Informatika Kota Batu. Jurnal JIMMU, Vol. II No. 2.

Syam, A., \& Amri. (2017, Juni). Pengaruh Kepercayaan Diri (Self Confidence) Berbasis Kaderisasi IMM Terhadap Prestasi Belajar Mahasiswa (Studi Kasus di Program Studi Pendidikan Biologi Fakultas Keguruan dan Ilmu Pendidikan Universitas Muhammadiyah Pare-Pare). Jurnal Biotek, Vol. 5 No. 1.

Syaputra, A., Wasnury, R., \& Rama, R. (2017, Februari). Pengaruh Loyalitas Kerja Dan Pelatihan Kerja Terhadap Peningkatan Produktivitas Kerja Karyawan Pada Perusahaan Daerah Air Minum (Pdam) Tirta Siak Kota Pekanbaru. Jurnal Online Mahasiswa Fakultas Ekonomi (JOM FEKON), Vol. 4 No. 1.

Vionita, G., Sitepu, M., \& Panjaitan, F. (2017, November). Analisis Pengaruh Disiplin Kerja, Loyalitas Dan Pengalaman Kerja Terhadap Kinerja Kerja Karyawan Pada Pt. Bank Tabungan Negara (Persero), Tbk Cabang Pangkal Pinang. Jurnal Ilmiah Progresif Manajemen Bisnis (Jipmb), Vol. 18 No. 2.

Yusuf, A. A., \& Hamzah, A. (2016). Pengaruh Kepercayaan Diri dan Semangat Kewirausahaan Terhadap Minat Menjadi Wirausaha. Jurnal Al-Amwal, Vol. 8 No. 2.

Zahara, H. (2014). Pengaruh Insentif Dan Semangat Kerja Terhadap Prestasi Kerja Penyuluh Lapangan Keluarga Berencana Di Badan Pemberdayaan Masyarakat dan Keluarga Sejahtera Kabupaten Aceh Utara. Jurnal Administrasi Publik dan Birokrasi, Vol. 1 No. 1. 